\title{
Aging Changes in Voltage-Gated Calcium Currents in Hippocampal CA1 Neurons
}

\author{
Lee W. Campbell, Su-Yang Hao, Olivier Thibault, Eric M. Blalock, and Philip W. Landfield \\ Department of Pharmacology, College of Medicine, University of Kentucky, Lexington, Kentucky 40536
}

Previous current-clamp studies in rat hippocampal slice CA1 neurons have found aging-related increases in long-lasting calcium (Ca)-dependent and Ca-mediated potentials. These changes could reflect an increase in $\mathrm{Ca}$ influx through voltagegated $\mathrm{Ca}$ channels but also could reflect a change in potassium currents. Moreover, if altered $\mathrm{Ca}$ influx is involved, it is unclear whether it arises from generally increased $\mathrm{Ca}$ channel activity, lower threshold, or reduced inactivation. To analyze the basis for altered Ca potentials, whole-cell voltage-clamp studies of CA1 hippocampal neurons were performed in nondissociated hippocampal slices of adult (3- to 5-month-old) and aged (25to 26-month-old) rats. An aging-related increase was found in high-threshold $\mathrm{Ca}$ and barium $(\mathrm{Ba})$ currents, particularly in the less variable, slowly inactivating (late) current at the end of a depolarization step. Input resistance of neurons did not differ between age groups. In steady-state inactivation and repetitive-pulse protocols, inactivation of $\mathrm{Ca}$ and $\mathrm{Ba}$ currents was not reduced and, in some cases, was slightly greater in aged neurons, apparently because of larger inward current. The current blocked by nimodipine was greater in aged neurons, indicating that some of the aging increase was in L-type currents. These results indicate that whole-cell $\mathrm{Ca}$ currents are increased with aging in CA1 neurons, apparently attributable to greater channel activity rather than to reduced inactivation. The elevated $\mathrm{Ca}$ influx seems likely to play a role in impaired function and enhanced susceptibility to neurotoxic influences.

Key words: hippocampus; aging; calcium currents; inactivation; afterhyperpolarization; neurotoxicity; barium currents; calcium homeostasis; Alzheimer's disease
Increasing evidence gathered over more than a decade has pointed to altered neuronal calcium $(\mathrm{Ca})$ homeostasis as a correlate of brain aging (for review, see Khachaturian, 1984, 1989; Gibson and Peterson, 1987; Landfield, 1987, 1995; Landfield et al., 1992; Michaelis et al., 1992; Disterhoft et al., 1993, 1994; Michealis, 1994). Several Ca regulatory processes have been implicated in this Ca dysregulation, including those involved in the buffering and extrusion of cytosolic Ca (Michaelis et al., 1984, 1989; Peterson and Gibson, 1984; Gibson and Peterson, 1987; Martinez-Serrano et al., 1992).

In addition, it appears that voltage-gated $\mathrm{Ca}$ influx may be elevated in aged hippocampal neurons. An aging-related increase in voltage-activated potentials that are $\mathrm{Ca}$-mediated or $\mathrm{Ca}$ dependent [e.g., the $\mathrm{Ca}$ action potential and the Ca-dependent afterhyperpolarization (AHP)] has been found consistently in CA1 neurons of rats (Landfield and Pitler, 1984; Kerr et al., 1989; Pitler and Landfield, 1990) and rabbits (Moyer et al., 1992; Disterhoft et al., 1993). Furthermore, hippocampal frequency potentiation (facilitation), a form of short-term synaptic plasticity that is impaired in aging rats, also is Ca-dependent. This type of facilitation can be strengthened in aging rat hippocampal neurons by elevating external magnesium (Mg) (Landfield et al., 1986), which blocks Ca influx through both voltage- and receptor-operated

Received May 15, 1996; revised July 10, 1996; accepted July 15, 1996.

This work was supported in part by grants from the National Institute on Aging (AG04542 and AG10836) and Bayer, Inc. We thank Lisa Lowery for excellent assistance with this manuscript.

Correspondence should be addressed to Dr. Philip W. Landfield, Department of Pharmacology, College of Medicine, University of Kentucky Medical Center, MS305, Lexington, KY 40536-0084.

Dr. Campbell's present address: The Salk Institute, La Jolla, CA 92037.

Dr Hao's present address: Department of Microbiology and Molecular Genetics, University of Kansas Medical Center, Kansas City, KS 66160.

Copyright (C) 1996 Society for Neuroscience $0270-6474 / 96 / 166286-10 \$ 05.00 / 0$
Ca channels (Lansman et al., 1986; Mayer and Westbrook, 1987).

Several factors could account for an aging-related increase in long-lasting Ca-mediated potentials. Not all potassium (K) currents are blocked under the current-clamp protocols measuring voltage, and therefore reduced $\mathrm{K}$ currents could underlie the prolongation and/or increased amplitude of Ca-mediated potentials. Alternatively, if the aging changes do arise from altered $\mathrm{Ca}$ channel activity, several possible factors could underlie these changes, including an increase in available Ca channels (Thibault and Landfield, 1996), a decrease in threshold for Ca current activation, or reduced sensitivity of $\mathrm{Ca}$ currents to inactivation. However, these factors have not yet been evaluated in detail in the CA1 neurons in which increased Ca-mediated potentials have been found.

High-threshold voltage-gated $\mathrm{Ca}$ currents in neurons are subject to $\mathrm{Ca}$ current-dependent inactivation as well as to voltagedependent inactivation in a wide range of excitable cells (Eckert and Chad, 1984; Armstrong and Eckert, 1987; Obejero-Paz et al., 1991; Imredy and Yue, 1992), including hippocampal pyramidal neurons (Pitler and Landfield, 1987; Nistri and Cherubini, 1990; Kay, 1991). Moreover, independent voltage- and Ca-dependent forms of inactivation processes coexist in some of the same cell types (Hadley and Lederer, 1991; Kay, 1991; Obejero-Paz et al., 1991). Clearly, a reduction of Ca- (or voltage)-dependent inactivation processes in aged neurons could be a factor in the increase in long-lasting Ca-mediated potentials in CA1 neurons. Rather than a reduction, several investigators instead have observed aging-related increases or no age differences in the inactivation of Ca currents, but this has been in other neuron types and in the context of different overall results (Reynolds and Carlen, 1989; 
Kostyuk et al., 1993; Murchison and Griffith, 1995) (see Discussion).

Thus, the mechanistic basis of the aging-related increase in $\mathrm{Ca}$ influx in CA1 neurons or, in fact, whether such an increase in high-threshold current even is observed in CA1 neurons under whole-cell voltage clamp remains uncertain. To address these questions, voltage-clamp analyses were carried out in the present study, using the intracellular sharp electrode voltage-clamp (SEVC) method (Johnston et al., 1980) in nondissociated hippocampal slices to minimize alteration of the internal milieu of the neurons.

\section{MATERIALS AND METHODS}

Animals used in these experiments were healthy, male Fischer 344 (F344) rats obtained from the National Institute on Aging-sponsored Harlan Industries specific-pathogen-free colony. Rats were 3-5 months (young adult) or 25-26 months (aged) of age when used and were housed in an air-barrier protected system before use. Slices were prepared and maintained using techniques generally similar to those described elsewhere (for review, see Dingledine, 1984) (see also Pitler and Landfield, 1990; Thibault et al., 1994). After decapitation, the brains were removed rapidly and chilled to $0^{\circ} \mathrm{C}$ in artificial CSF (ACSF). The hippocampi were carefully dissected free and placed on the tissue chopper. Approximately ten 450-mM-thick slices were cut from the middle of each hippocampus transverse to its longitudinal axis. The slices were maintained in an interface type recording chamber at a temperature of $32.5^{\circ} \mathrm{C}$.

A nylon mesh net supported slices at the interface of an atmosphere of moistened $95 \% \mathrm{O}_{2} / 5 \% \mathrm{CO}_{2}$ and the ACSF bath containing (in $\mathrm{mM}$ ): $\mathrm{NaCl}$ $128, \mathrm{KH}_{2} \mathrm{PO}_{4} 1.25$, glucose $10, \mathrm{NaHCO}_{3} 26, \mathrm{KCl} 3, \mathrm{CaCl}_{2} 2, \mathrm{MgCl}_{2} 2$. Before recording, slices were allowed to equilibrate with the medium and recover for $1 \mathrm{hr}$.

Borosilicate glass micropipettes (World Precision Instruments, Gaitherburg, MD), pulled on a Sutter Instruments $\mathrm{P}-80 / \mathrm{PC}$ puller (Novato, CA) (70-100 $\mathrm{M} \Omega$, filled with $2 \mathrm{M}$ cesium $\left.(\mathrm{Cs}) \mathrm{Cl}_{2}, \mathrm{pH} 7.15\right)$, were used to impale CA1 neurons. Data were recorded in both current-clamp and discontinuous SEVC modes (Axoclamp 2A, Axon Instruments, Foster City, CA) and displayed on a digital storage oscilloscope (Nicolet model 3091). Cells generally were voltage-clamped with a $2-3 \mathrm{kHz}$ sampling frequency using the continuous output of the headstage to ensure full decay of voltage across the electrode before each sampling point. The long time constants of these neurons $(15-25 \mathrm{msec})$ met the requirements for effective discontinuous voltage clamp (e.g., membrane time constant $\gg$ electrode time constant) even with these high resistance micropipettes (cf. Johnston et al., 1980; Finkel and Redman, 1985). Leak subtraction was performed digitally on-line by the method of fractional hyperpolarizing pulses. The data were stored and analyzed off-line with cursors on a computer equipped with TECMAR analog/digital converter and math coprocessor using programs developed in the laboratory based on ASYST Technologies software (L. Campbell, unpublished programs). Repeatedmeasures ANOVA and post hoc Bonferroni group comparisons were used to analyze responses of adult and aged rat neurons.

Although differences in the passive, electrotonic properties of the cell could result in altered control of regenerative voltages (Johnston and Brown, 1983; Spruston et al., 1994), this does not appear to be a factor in the present studies. Most intracellular studies have found that there are no major aging-related changes in the passive membrane properties [input resistance (IR) and time constants]) of several types of hippocampal neurons (cf. Barnes and McNaughton, 1980; Landfield and Pitler, 1984; Kerr et al., 1989; Reynolds and Carlen, 1989; Pitler and Landfield, 1990; Potier et al., 1993; Moyer and Disterhoft, 1994) (for review, see Barnes, 1994). In addition, although estimates in CA1 pyramids indicate that the electrotonic length is $\sim 0.9 \lambda$ (Brown et al., 1981; Johnston and Brown, 1983; Turner and Schwartzkroin, 1984), the large dendritic shafts, which with the soma contain the vast majority of L-type channels (Hell et al., 1993), are electrotonically close to the soma (e.g., 0.1-0.2 space constants). Cells in this study also were Cs-loaded, which presumably reduced electrotonic distance significantly (Johnston et al., 1980), and many of the currents were studied at the end of the pulse (late current) from a holding potential of $-40 \mathrm{mV}$, which enhanced clamp efficacy (see Results).

Inconsistent viability of slices and neurons can affect substantially the variance of Ca current recordings, making it extremely difficult to detect subtle aging changes. Therefore, all slices and cells included for analysis
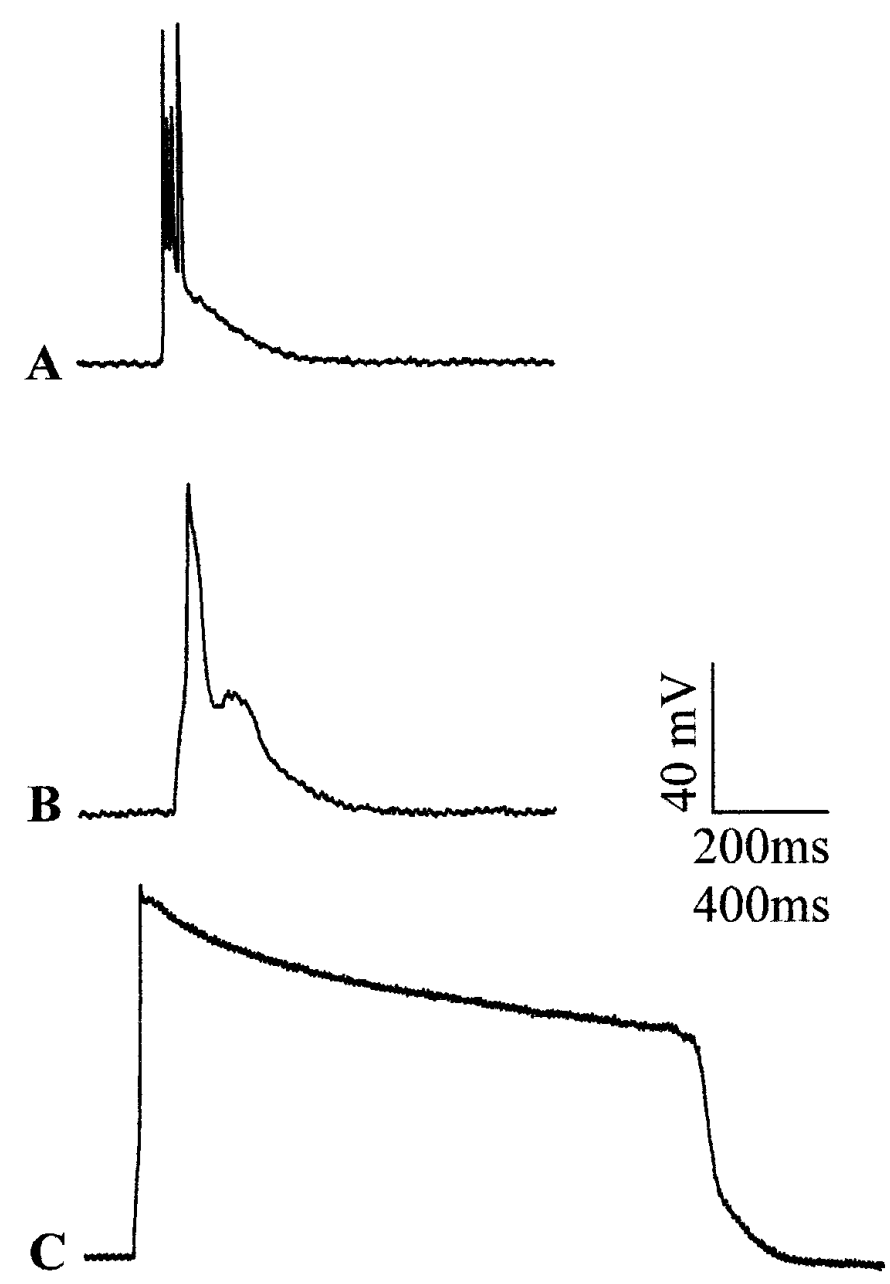

Figure 1. Voltage-response records of a Cs-loaded CA1 hippocampal neuron from a young animal. $A$, Intracellular current injection induces a burst of $\mathrm{Na}$ action potentials. Note that $2 \mathrm{M} \mathrm{CsCl}$ in the pipette blocks the AHP. B, Blocking Na action potentials with TTX unmasks a sharp Ca spike followed by a slow lower amplitude ("hump") phase lasting >200 msec. $C$, Additional block of repolarizing $\mathrm{K}$ conductances with TEA prevents repolarization of the sharp spike component resulting in a long $\mathrm{Ca}$ action potential plateau at near-maximum amplitude $(\sim 2 \mathrm{sec})$. All records are from the same cell and were recorded at a holding potential of $-70 \mathrm{mV} ; 400 \mathrm{msec}$ horizontal scale bar applies to $C$ only.

had to meet several rigorous criteria. A slice was considered healthy and usable in the present study if a population spike of $4-8 \mathrm{mV}$ amplitude could be recorded by an extracellular pipette (3-7 M $\Omega$ ) located in the CA1 pyramidal layer in response to a $100 \mu \mathrm{sec}, 300-400 \mu \mathrm{A}$ pulse applied through a bipolar stimulating electrode to the Schaffercommissural fibers and if other slices in the same well did not exhibit seizure-like activity during strong repetitive stimulation $(\sim 1000 \mu \mathrm{A})$ at 2 Hz. IR measurements were obtained from each cell (during a $40 \mathrm{msec}, 0.2$ $\mathrm{nA}$ constant current hyperpolarizing pulse) from a holding potential of $-70 \mathrm{mV}$. To reduce variability attributable to either cell size or poor health, only cells from healthy slices that exhibited sodium (Na) spikes of at least $75 \mathrm{mV}$, near-complete Cs blockade of the Ca-dependent AHP, and an IR between 35 and $65 \mathrm{M} \Omega$ were used in these studies. No age differences were found in the proportions of neurons meeting these criteria.

For cells meeting the criteria above, tetrodotoxin (TTX) $\left(1 \times 10^{-6} \mathrm{M}\right)$ was applied to the bath to block Na spikes (Fig. 1). After Cs loading and application of TTX, a Ca action potential (spike) was elicited in currentclamp mode (Fig. $1 B$ ) by holding the cell at $-70 \mathrm{mV}$ and applying an intracellular $40 \mathrm{msec}$ constant current depolarizing pulse (at $150 \%$ of threshold for the Ca spike). For subsequent study in voltage-clamp mode, slices then were treated with tetraethylammonium chloride (TEA) (5 
$\mathrm{mM}$ ) to block most remaining voltage-activated $\mathrm{K}$ conductances (Storm, 1990). Efficacy of TEA block was assessed for each neuron used in these studies by the occurrence of a substantial prolongation of the plateau of the initial fast component of the Ca spike (from $\sim 30 \mathrm{msec}$ without TEA to about $\sim 3000 \mathrm{msec}$ with TEA) and was checked repeatedly throughout the experiment and strengthened by adding TEA if necessary (Fig. 1C).

In some studies, the dihydropyridine (DHP) L-type Ca channel antagonist nimodipine (Bayer, West Haven, CT) was applied to the bath at a saturating final concentration of $10 \mathrm{~mm}$. This concentration is substantially higher than necessary to saturate L channels (McCarthy and TanPiengco, 1992) but was used in light of the variable drug availability and diffusion that occurs in a thick slice preparation. Nimodipine was mixed in stock solutions with $100 \%$ ethanol and protected from light during storage and throughout the experiments. The stock solutions were mixed with ACSF to achieve a final alcohol dilution of no more than $0.05 \%$.

\section{RESULTS}

\section{Calcium action potentials (spikes)}

Before performing the voltage-clamp studies, it was important to ensure that the particular cells being analyzed in this study also showed the aging-related increases in Ca spikes that had been seen previously. Therefore, before establishing voltage clamp, neurons were run through a Ca spike measurement and inactivation protocol similar to those used in previous studies. Under our conditions (Pitler and Landfield, 1987, 1990), Ca spikes exhibit two distinct phases: (1) a fast spike component with a sharp onset and peak amplitude of $\sim 80 \mathrm{mV}$, lasting 20-30 msec, and (2) a subsequent lower amplitude plateau phase, or "hump," component lasting $\sim 200-250 \mathrm{msec}$, followed by a gradual return to resting membrane potential (Fig. $1 B$ ) (see also Disterhoft et al., 1993). After stabilization, Ca spike duration, amplitude, and inactivation during a $2 \mathrm{~Hz}$ train of depolarizing current pulses ( $150 \%$ threshold) were measured. As shown in Figure $2 A$, the aged rat CA1 neurons in the present study exhibited longer $\mathrm{Ca}$ spike durations than did neurons from young-adult rats $\left(F_{(1,39)}=\right.$ 14.9, $p<0.001$; adult cells, $n=28$; aged cells, $n=13)$, replicating earlier findings (Pitler and Landfield, 1990; Disterhoft et al., 1993). Again, no differences in peak spike amplitude were observed. Inactivation of the $\mathrm{Ca}$ spike during repetitive activation has been shown previously to be Ca-dependent, because it is much reduced in barium (Ba) (Pitler and Landfield, 1987). The present studies also replicated the observation that $\mathrm{Ca}$-dependent inactivation of the $\mathrm{Ca}$ spike is not reduced with aging (Pitler and Landfield, 1990) and, in fact, may have been somewhat increased in the present study, as indicated by a significant interaction between age and the train of five consecutive depolarizations elicited at $2 \mathrm{~Hz}\left(F_{(4,156)}=7.80 ; p<0.001\right)$ (Fig. $\left.2 B\right)$. This interaction appears to reflect somewhat steeper inactivation between the first and second pulses in the aged neurons (Fig. 2B). Thus, this population of neurons showed aging changes in longlasting Ca-mediated potentials similar to those seen previously and, therefore, provided an appropriate population in which to investigate the underlying currents in voltage-clamp mode. In addition, as in earlier studies in rat brain neurons (Barnes and McNaughton, 1980; Landfield and Pitler, 1984; Kerr et al., 1989; Potier et al., 1993; Barnes, 1994), IR of neurons did not differ with aging (adult, $47 \pm 3.1 \mathrm{M} \Omega$, aged $48.3 \pm 2.7 \mathrm{M} \Omega$ ), indicating that neurons from the two age groups generally were similar in size and passive electrotonic structure.

\section{Ca currents}

After voltage measures were obtained, neurons were treated with TEA to block most of the remaining $\mathrm{K}$ conductances (Fig. $1 C$ ), and the recording mode was changed from current clamp to
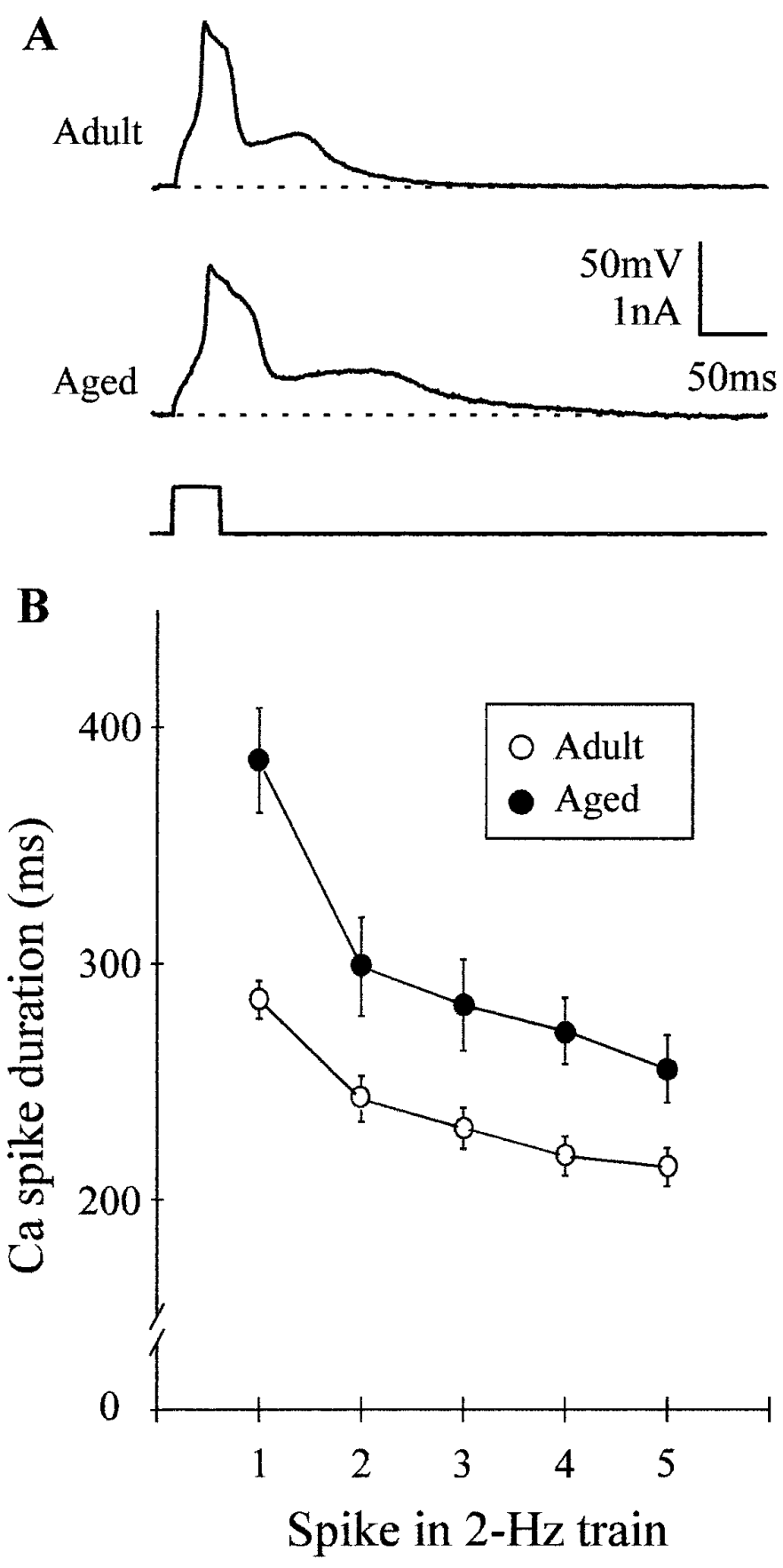

Figure 2. Aging effects on Ca action potentials. $A$, Representative examples of Ca spike potentials from CA1 neurons of adult (top) and aged (bottom) animals. The third trace illustrates the intracellular constant current pulse $(40 \mathrm{msec})$ used to trigger the Ca spike. The "hump" or slow plateau phase is consistently larger and prolonged in spikes from aged neurons. However, peak amplitude of the fast spike phase is not different with aging. $B$, Mean \pm SEM. Effects of repetitive stimulation $(2 \mathrm{~Hz}$ train, $40 \mathrm{msec}$ pulses) in 28 adult and 13 aged rat neurons on the inactivation of Ca spike duration. Relative inactivation was unchanged or slightly greater in the aged rat neurons, possibly reflecting larger $\mathrm{Ca}$ influx.

discontinuous voltage clamp. Figure $3 A$ illustrates the appearance of voltage-activated $\mathrm{Ca}$ currents in these neurons and the degree of voltage control at different holding potentials. The larger, more rapidly inactivating current on the left was evoked by depolarization from $-70 \mathrm{mV}$. Under these conditions, the peak of this 
A
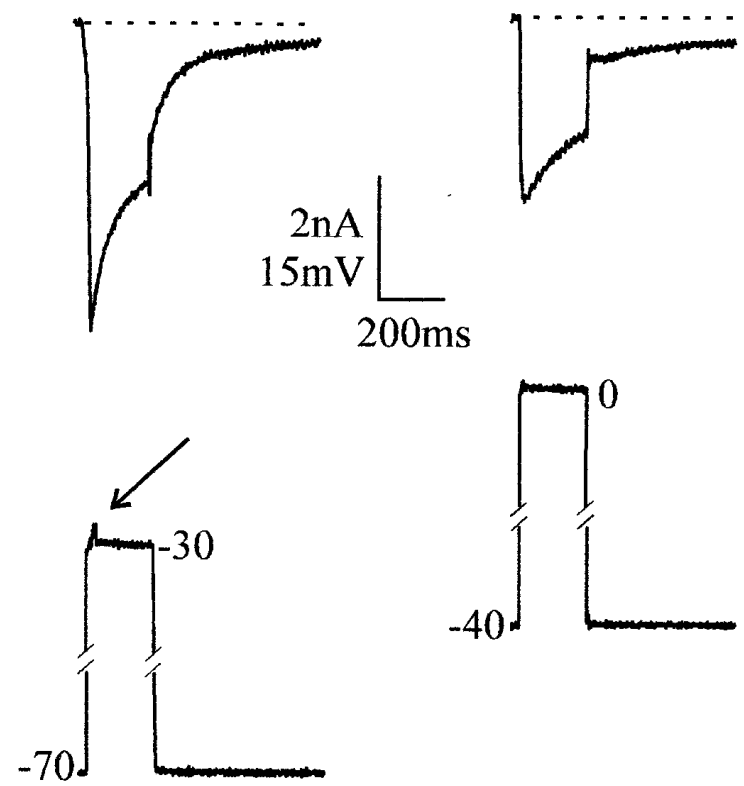

B

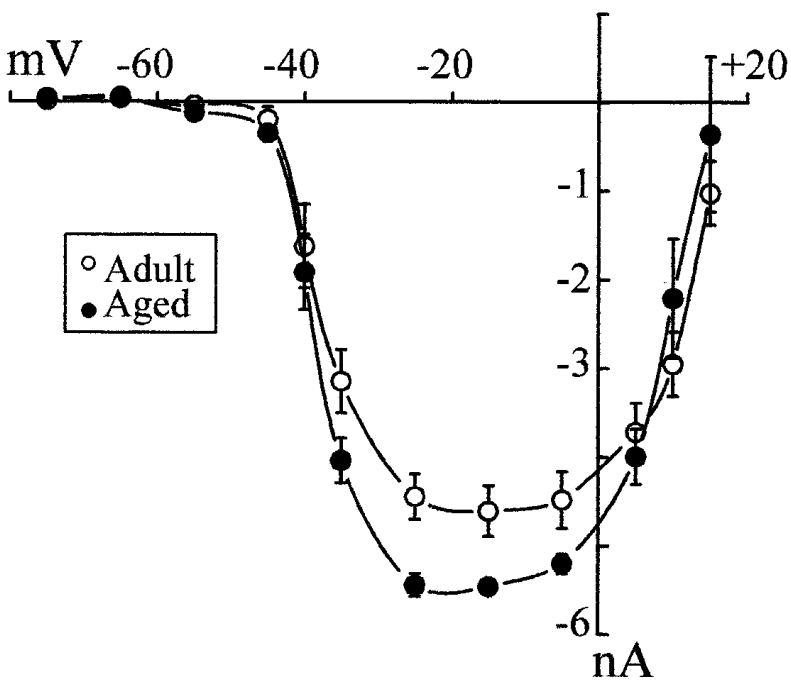

Figure 3. Voltage-clamp efficacy and voltage dependence of Ca currents. $A$, Traces acquired during a similar voltage step amplitude $(40 \mathrm{mV})$ from different holding potentials. The upper left trace reflects a large rapidly inactivating current elicited from $-70 \mathrm{mV}$, whereas the actual voltage trace obtained during that depolarization (bottom left) shows a sharp deviation from the imposed voltage at the peak of the current (arrow). The efficacy of the voltage clamp can be improved by holding the cell at -40 $\mathrm{mV}$, which inactivates much of the current (upper right). The voltage control during the pulse (bottom right) is improved substantially. A prominent long tail current followed the depolarization induced current (see text) but was not assessed in these studies. $B$, Mean \pm SEM for peak currents of a subset of neurons in each age group (adult, $n=6$ neurons; aged, $n=5$ neurons). Cells were held at $-80 \mathrm{mV}$ and stepped to $+15 \mathrm{mV}$ in increments of $5 \mathrm{mV}$. All points are not plotted.

current was difficult to clamp completely with the SEVC, as shown by the error in the clamp voltage (Fig. $3 \mathrm{~A}$, arrow, bottom left) (see also Johnston et al., 1980; Finkel and Redman, 1985). However, much of this initial large peak current could be inactivated at a holding potential of $-40 \mathrm{mV}$ (right) allowing a substantially more effective clamp (Fig. $3 A$, bottom right) (see also Gähwiler and Brown, 1987; Nistri and Cherubini, 1990). Therefore, the more slowly inactivating Ca currents, which include the L-type and some N- and P/Q-type currents (Fox et al., 1987; Llinas et al., 1989; Plummer et al., 1989; Swartz and Bean, 1992; Eliot and Johnston, 1994; Randall and Tsien, 1995), appear to be studied more accurately by holding at $-40 \mathrm{mV}$. In addition, because of inactivation during the pulse, measurement accuracy was enhanced further by measuring current at the end of the depolarizing command step (late current) rather than at the peak. Consequently, many of the aging comparisons were performed from a holding potential of $-40 \mathrm{mV}$, and late current generally was measured along with peak current.

Because of this difficulty in accurately clamping the large, rapidly inactivating peak currents, a current-voltage $(I-V)$ analysis of activation patterns was not performed for each neuron in this study. However, $I-V$ relations were studied in subsets of adult and aged neurons in which the clamp appeared to be most effective (as determined by a gradual activation curve and minimal loss of control in the voltage trace). In these subsets ( $n=6$ adult and 5 aged neurons), the voltage dependence of the Ca currents appeared similar in adult and aged neurons with maximum current elicited during steps to the -20 to $-10 \mathrm{mV}$ range (Fig. $3 B$ ). Consequently, activation protocols for aging comparisons in the present studies ensured full activation by employing voltage command steps to $0 \mathrm{mV}$, well above maximum. A prominent longlasting tail current generally follows each depolarization pulse (Fig. 3A). As shown in Figure $3 A$ (right), the long tail often exhibits a delayed activation at lower holding potentials. These long tail currents are observed consistently in adult slice hippocampal neurons (Pitler and Landfield, 1987; Nistri and Cherubini, 1990; Kerr et al., 1992) and resemble a space-clamp artifact that could arise from unclamped distal dendrites. However, single Ca channel openings during the repolarization period that follows a depolarization pulse also are observed on the somata of hippocampal neurons (Fisher et al., 1990; Thibault et al., 1993, Kavalali and Plummer, 1996). In addition, several lines of evidence indicate that the long tail current is a $\mathrm{Ca}$ current and that it does not arise in the large apical dendrite (Thibault et al., 1995). On the other hand, the single-channel openings on the soma during the repolarization phase do not seem sufficient to account for these large tails under relatively physiological conditions. Therefore, the tail currents may arise from a combination of repolarization openings of $\mathrm{Ca}$ channels and unclamped small dendrites. However, this is a complex and unresolved issue, and the tail current was not investigated systematically in the present study.

\section{Steady-state inactivation}

Patterns of the voltage dependence of inactivation of the $\mathrm{Ca}$ currents were studied using a steady-state inactivation (or $h$-infinity) protocol in which the holding potential was maintained for prolonged periods at different voltages. Ca currents during 200 msec depolarizing steps to $0 \mathrm{mV}$ were measured in each neuron from increasingly positive holding potentials, which were incremented in shifts of $5 \mathrm{mV}$, beginning at $-60 \mathrm{mV}$. Cells were held for $5 \mathrm{sec}$ at each of the nine increasingly positive holding potentials, before the $200 \mathrm{msec}$ depolarizing step. Figure $4 A$ shows averaged traces for adult $(n=13)$ and aged $(n=9)$ rat neurons studied in this paradigm. Figure $4, B$ and $C$, shows the statistical 
Figure 4. Averaged traces of Ca currents activated by $200 \mathrm{msec}$ depolarizing voltage steps to $0 \mathrm{mV}$ from increasingly positive holding potentials (steady-state inactivation protocol). $A$, Traces shown are averages of the current responses of CA1 neurons from young-adult $(n=13)$ and aged $(n=9)$ animals. The voltage protocols (bottom) are schematic representations. $B$, Mean \pm SEM for the peak currents for the cells averaged in $A$. $C$, Mean \pm SEM for late current measures for the cells shown in $A$. At increasingly positive voltages, the rapidly inactivating component decreased relatively more than the late current measured at the end of the pulse. Currents from aged neurons were larger than currents from young-adult neurons, although the differences decreased with increasing inactivation at higher voltages. Both a significant main effect of age and a significant interaction between age and holding potential (reflecting the disappearance of the aging effect at more positive, inactivating voltages) were found.
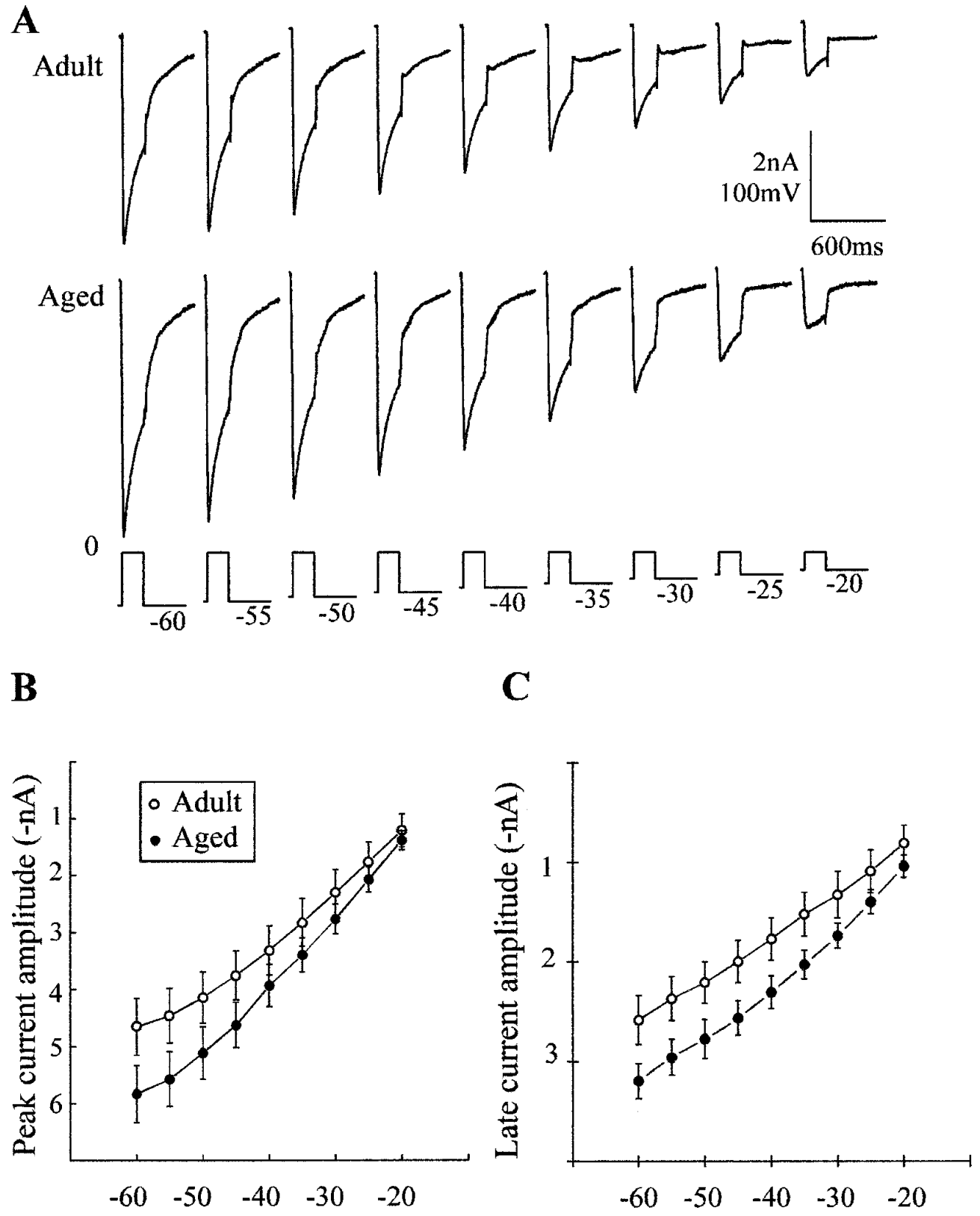

Holding potential $(\mathrm{mV})$ data (mean \pm SEM) for peak current $(B)$ and late current at the end of the command step $(C)$ for the averaged currents shown in $A$. Currents at both the peak and the end (late current) of the step were larger in aged rat neurons when assessed by $t$ test at only the holding potential of $-60 \mathrm{mV}(p<0.01)$. However, ANOVA across all holding potentials examined in the steady-state inactivation protocols showed that the main effect of age was not significantly different for peak currents over the full range of holding potentials. This was because the current amplitudes for the two age groups became less different at higher holding potentials (Fig. 4B). Nevertheless, a significant main effect of age (by ANOVA) was present for the late current (Fig. $4 C$ ) across all holding potentials $\left(F_{(1,20)}=7.52 ; p<0.02\right)$. Thus, high-threshold Ca currents were larger in aged rat neurons, particularly for the slowly inactivating late current measured at the end of the step.
As noted, the age difference in current amplitude was diminished at more positive holding potentials, particularly above $-40 \mathrm{mV}$, resulting in a highly significant interaction term in the two-way ANOVA between age and holding potentials $\left(F_{(8,160)}\right.$ $=3.33 ; p<0.002$ for late current) (Fig. $4 C$ ). This appears to reflect greater steady-state inactivation of high-threshold $\mathrm{Ca}$ currents in the aged group, particularly at the higher holding potentials. However, given that $\mathrm{Ca}$ current influx occurs at potentials above approximately $-40 \mathrm{mV}$ (Fig. $3 B$ ), this protocol does not clearly separate contributions from voltage- and Ca-dependent forms of inactivation.

The degree of inactivation during a pulse to $0 \mathrm{mV}$ from a holding potential of $-60 \mathrm{mV}$ also was evaluated for these neurons. No aging difference was found in the inactivation during the pulse, either as determined by the percent decrease 
A

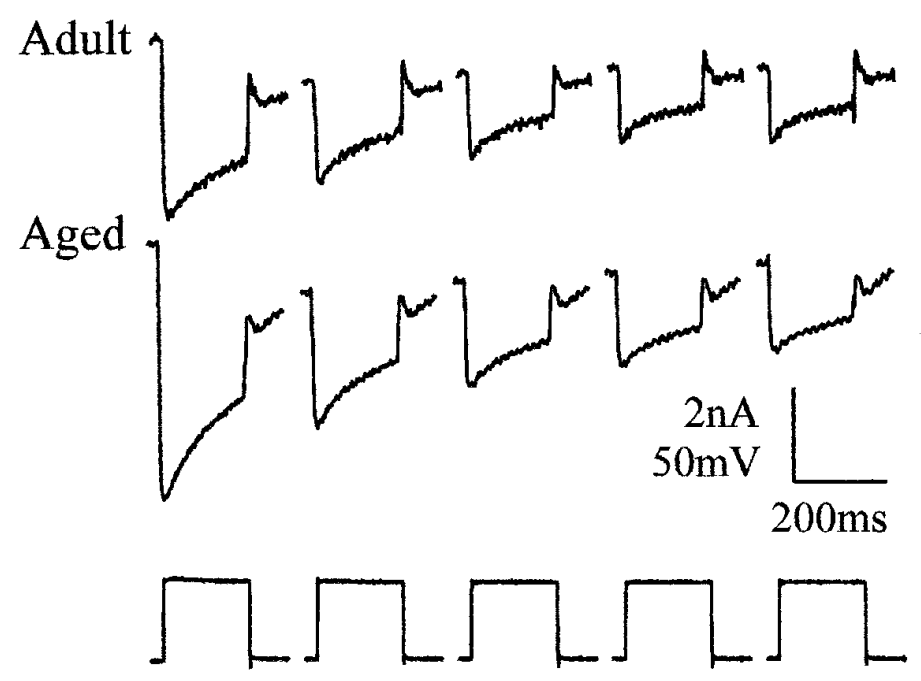

\section{B Calcium}
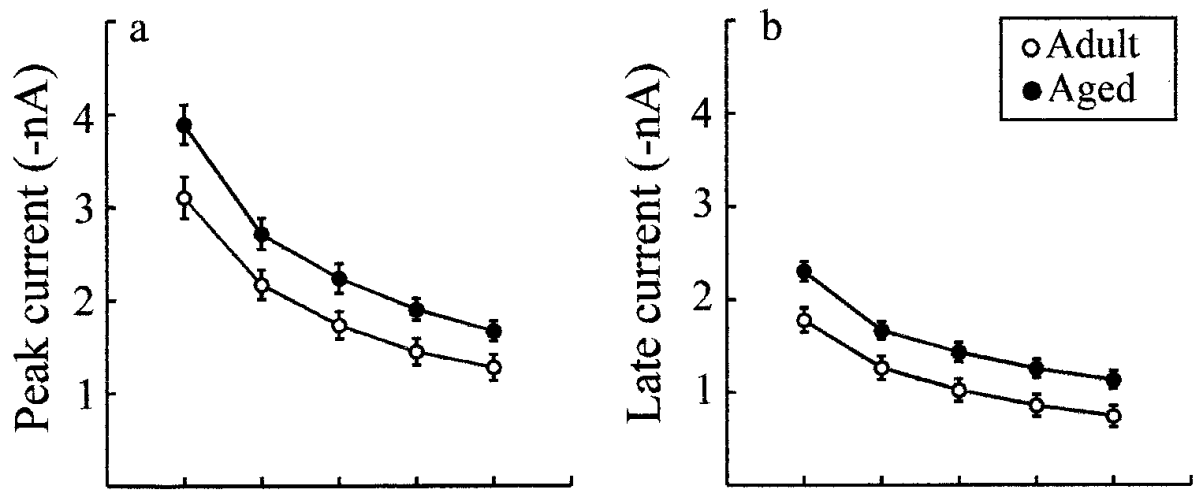

C Barium
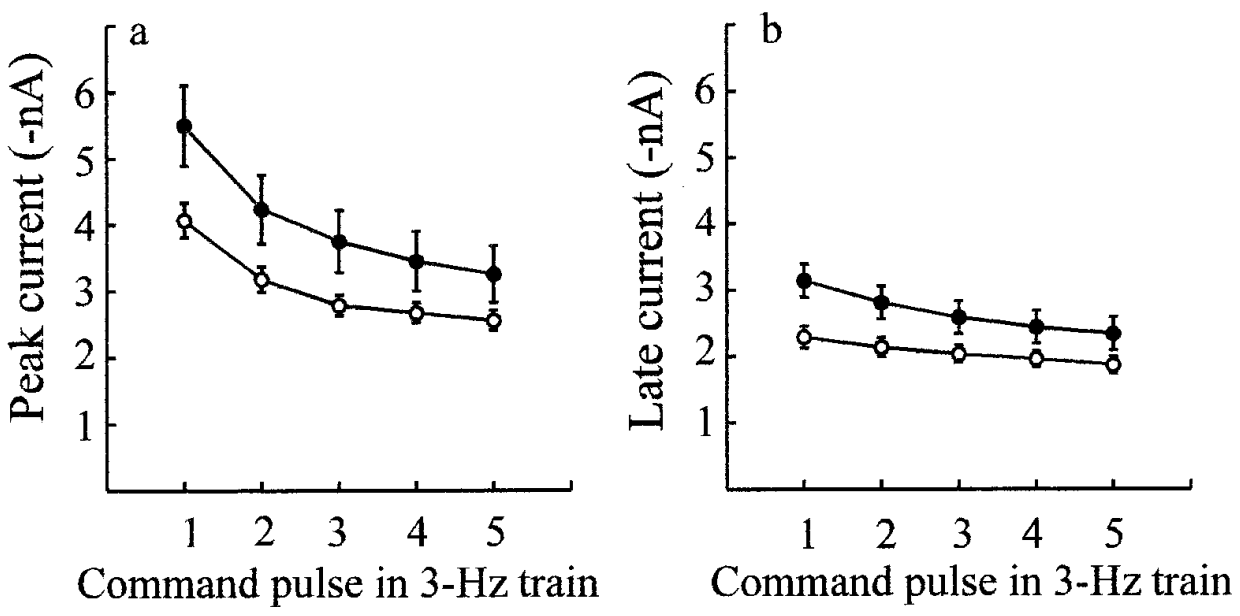

Figure 5. A, Representative examples of $\mathrm{Ca}$ currents elicited by repetitive $3 \mathrm{~Hz}$ depolarizing voltage steps to $0 \mathrm{mV}$ from a holding potential of $-40 \mathrm{mV}$ from a CA1 neuron of a young-adult animal (top) and an aged animal (bottom). Voltage steps (actual) shown in the lowest trace of $A$ are from the aged cell shown above. Currents were obtained for five $200 \mathrm{msec}$ pulses given at $3 \mathrm{~Hz}$. Holding potentials of -40 $\mathrm{mV}$ reduced the rapidly inactivating component and allowed more accurate measures of the slowly inactivating Ca current. $B$, Mean \pm SEM of peak $(a)$ and late $(b)$ current measured in the protocol shown in $A$. The charge carrier was $2 \mathrm{~mm} \mathrm{Ca}$. Both peak and late $\mathrm{Ca}$ currents were significantly larger in neurons from aged $(n=$ $22)$ than from young adult $(n=25)$ animals, but a significant interaction was found between age and repetitive pulses only for peak current $(a)$. $C$, Mean \pm SEM of peak $(a)$ and late $(b)$ current in neurons $(n=12$ adult and 11 aged neurons) with $\mathrm{Ba}(2 \mathrm{~mm})$ substituted for $\mathrm{Ca}$ as the charge carrier. The aging difference still is apparent, but the overall rate of inactivation is slowed. However, a significant interaction between age and repetitive pulses was present for both peak and late currents, possibly reflecting greater inactivation in the aged group. in current from beginning to end of the pulse or by the time constant of the decay. In young-adult rat neurons, the percent decrease during the pulse was $42.8 \pm 3.0 \%$, whereas in aged rat neurons, the decrease was $46.2 \pm 1.9 \%$. The average time constant of decay over the $200 \mathrm{msec}$ pulse was $51.3 \mathrm{msec}$ for the adult rat neurons and $60.1 \mathrm{msec}$ for the aged rat neurons.

\section{Repetitive-pulse inactivation}

Measurements of Ca-dependent inactivation of $\mathrm{Ca}$ currents were obtained more directly in experiments using a $3 \mathrm{~Hz}$ repetitiveactivation train of five depolarizing pulses (to $0 \mathrm{mV}, 200 \mathrm{msec}$ each, from a holding potential of $-40 \mathrm{mV}$ ) (Fig. $5 A$ ). Previous studies have shown that current decline in the later pulses of the 
train in this protocol directly reflects $\mathrm{Ca}$-dependent inactivation in these neurons, because the degree of inactivation is reduced when $\mathrm{Ba}$ is the charge carrier and because no detectable outward currents are present between pulses (Pitler and Landfield, 1987). In 25 adult and 22 aged neurons, a significant main effect of age was found on peak current (Fig. $5 B, a$ ) across the $3 \mathrm{~Hz}$ train $\left(F_{(1,45)}=6.07 ; p<0.02\right)$. In addition, the main effect of repetitive stimulation was highly significant $(p<0.001)$. The interaction between age and repeated pulses also was significant $\left(F_{(4,180)}=\right.$ 2.96; $p<0.03)$, again reflecting a difference in the inactivation pattern between the young and aged groups. As with the Ca spike data (Fig. $2 B$ ), this interaction appeared to result primarily from relatively steeper inactivation between the first and the second pulses in the aged group. However, it is difficult to conclude that inactivation generally was greater in the aged group, because when currents were normalized to the first pulse in each neuron, no significant age differences were observed in the decline of fractional current across pulses (data not shown). Late current (Fig. $5 B, b)$ also showed a significant main effect of age $\left(F_{(1,45)}=\right.$ $7.21 ; p<0.01)$, although a significant interaction with repetitive pulses was not seen. As with peak current, analyses of normalized fractional late current did not show an age difference (data not shown).

A similar experiment was performed on a different set of cells (adult, $n=12$; aged, $n=11)$ in which $\mathrm{Ba}(2 \mathrm{mM})$ was substituted for $\mathrm{Ca}$ as the primary external divalent cation charge carrier (Fig. $5 C, a, b)$. In $\mathrm{Ba}$, overall currents were larger, and the general degree of inactivation was reduced compared with Ca-bathed cells, as would be anticipated from the relatively greater permeability of Ba through Ca channels (Tsien et al., 1988) and its relatively weaker effect in inducing current-dependent inactivation of Ca channels (Eckert and Chad, 1984; Pitler and Landfield, 1987; Kay, 1991; Obejero-Paz et al., 1991). Nevertheless, aging effects were analogous to those in $\mathrm{Ca}$ in that the main effect of aging was significant across the five-pulse train for the late current $\left(F_{(1,21)}=4.8, p<0.04\right)$. Some differences from Ca were noted, however, in that main effects of age on peak current were not significant (apparently reflecting greater variability attributable to larger peak amplitudes in $\mathrm{Ba}$ ), but a highly significant interaction was found between age and repeated stimulation $\left(F_{(4,84)}=14\right.$, $p<0.001)$ for late current, again possibly reflecting greater inactivation during the train in the aged rat neurons (Fig. 5C). This latter conclusion was supported by the observation that, unlike the results in $\mathrm{Ca}$ medium, ANOVAs of normalized currents revealed significant main effects of aging resulting from a greater decline of fractional current for aged neurons on both peak $(p=0.05)$ and late $(p<0.002)$ currents (data not shown). Although not as effective as $\mathrm{Ca}, \mathrm{Ba}$ can induce current-dependent inactivation in the hippocampus (Kay, 1991) as well as other cell types (Fedulova et al., 1985; Kasai and Aosaki, 1988; Mazzanti et al., 1991a). Thus, although some differences are seen between $\mathrm{Ba}$ and Ca currents, possibly related to different current amplitudes or inactivation efficacies, overall, the repetitive-activation studies indicate that the degree of inactivation of $\mathrm{Ca}$ channel currents was not reduced with aging and, instead, may have been slightly greater in some experiments.

\section{Contribution of L-type channels}

L-type channels appear to contribute to the Ca-mediated potentials that are increased with aging (see below), and therefore the effects of nimodipine, a DHP L-type channel antagonist, were investigated in a subset (adult, $n=4$; aged, $n=4$ ) taken from the same cells shown in Figure $5 B$. Each of those cells was exposed to saturating concentrations of nimodipine $(10 \mathrm{~mm}) \sim 15 \mathrm{~min}$ after the initial protocols (Fig. 5). At 10 min after initial nimodipine exposure, peak $\mathrm{Ca}$ currents again were measured. Nimodipine reduced peak $\mathrm{Ca}$ currents significantly in both the young-adult (paired $t$ test, $p<0.03)$ and aged neurons $(p<0.02)$ to a degree consistent with several other whole-cell studies in hippocampal neurons using SEVC (Gähwiler and Brown, 1987) and patchclamp (Regan et al., 1991; Swartz and Bean, 1992; Eliot and Johnston, 1994) methods. In addition, the amount of current reduction was greater in the aged $(1.13 \pm 0.23 \mathrm{nA})$ than in the adult $(0.32 \pm 0.1 \mathrm{nA})$ neurons ( $p<0.05$ for difference currents) (data not shown). However, although the absolute current reduced by nimodipine was greater in aged neurons, studies with larger groups will be required to determine whether there is an age-related increase in the percentage of nimodipine-sensitive current relative to other $\mathrm{Ca}$ currents.

\section{DISCUSSION}

The present study provides direct evidence from whole-cell voltage-clamp measures, under conditions in which repolarizing $\mathrm{K}$ currents were well-blocked, that voltage-gated Ca currents in CA1 hippocampal neurons are increased significantly with aging. Although quantitative group comparisons are difficult to perform under voltage-clamp conditions, given the large variability in cell size and clamp efficacy, the use of holding potentials of $-40 \mathrm{mV}$ and measurements obtained at the end of a $200 \mathrm{msec}$ depolarizing pulse appeared to substantially improve reliability of the measurements. In addition, setting strict criteria for cell health and restricting the IR range ensured that poorly sealed, unhealthy, or very large or very small cells were excluded from the analysis. Although TEA and Cs do not block all K currents, they block most of the hyperpolarizing $\mathrm{K}$ currents on the time scale that might be expected to affect $\mathrm{Ca}$ current measures in this study (Storm, 1990), and each neuron used in the analyses was confirmed for K current blockade according to the protocol in Figure 1. Therefore, K currents do not appear to influence the Ca current data significantly. Thus, these results indicate that earlier findings on Ca-mediated potentials in CA1 neurons may be accounted for, at least in part, by an increase in overall Ca current influx at the whole-cell level.

Several other voltage-clamp studies have found results on $\mathrm{Ca}$ current influx that are somewhat contradictory to ours (Reynolds and Carlen, 1989; Kostyuk et al., 1993), and some have found similar results but for a different type (T) of Ca current (Murchison and Griffith, 1995). However, in those studies, cell types other than CA1 pyramidal neurons were investigated and/or different cell preparation and recording methods were used, some of which can be relatively traumatic. That other cell types exhibit patterns of aging changes different from those in CA1 neurons perhaps is not surprising, because many brain or peripheral regions (including dentate gyrus and dorsal root ganglion) (Reynolds and Carlen, 1989; Kostyuk et al., 1993) do not show major indications of neuropathology in aging or Alzheimer's disease (Coleman and Flood, 1987). In addition, although some studies have not replicated all statistically significant effects of aging on the AHP and Ca spike in CA1 neurons, in those studies, very similar nonsignificant or barely significant trends were observed (Potier et al., 1993). The slightly discrepant results appeared to be attributable to differences in rat strains and/or extracellular $\mathrm{Ca}$ concentrations (Potier et al., 1993).

Among the key questions on the aging-related increase in $\mathrm{Ca}$ 
currents is its underlying mechanistic basis. The results here clearly indicated that the increase in Ca current was not attributable to reduced inactivation processes, as determined either in repetitive-activation or steady-state inactivation protocols. Earlier current-clamp studies also had found no aging-dependent reduction in the Ca-dependent inactivation of $\mathrm{Ca}$ spikes (Pitler and Landfield, 1990). In some of the present analyses, moreover, there was a significant interaction term resulting from steeper initial inactivation (Figs. $2 B, 4 C, 5 B$ ) in aged cells or a greater fractional decline of current in aged neurons (Fig. $5 C$ ). These results appear to reflect a slightly enhanced degree of inactivation in aged neurons, although this effect did not appear to be substantial and likely was simply attributable to the greater current influx (see also Reynolds and Carlen, 1989). The steady-state inactivation protocol does not clearly separate voltage-dependent and $\mathrm{Ca}-$ dependent forms of inactivation, but the apparently greater inactivation in aged neurons appears confined to potentials above -40 $\mathrm{mV}$ (Fig. 4C). Because this is the approximate threshold for voltage-gated $\mathrm{Ca}$ influx (Fig. $3 B$ ), the greater inactivation in aged neurons in this protocol again simply could result from enhanced Ca influx.

Thus, the main result on inactivation relevant to the processes underlying increased $\mathrm{Ca}$ currents with aging was that a reduction of inactivation processes is not a likely candidate for the mechanism of aging-dependent enhancement of Ca current. Consequently, current-dependent inactivation processes appear to be at least as sensitive in aged as in adult CA1 neurons.

The present studies also indicated that the increase in $\mathrm{Ca}$ current influx does not appear to be attributable to altered threshold or voltage dependence, because no age differences were observed in the $I-V$ studies in subsets of cells (Fig. $3 B$ ) and voltage test pulses were stepped to potentials well above threshold in all cells used in comparisons of adult and aged neurons. However, this conclusion must be considered preliminary, because not every cell could be analyzed in a full $I-V$ protocol.

If reduced inactivation processes or a shift in voltage dependence do not account for the greater whole-cell Ca current, then it appears likely that $\mathrm{Ca}$ channel flux generally is elevated. This could occur through higher open probability, larger singlechannel conductance, or increased density of available channels. Recent single-channel studies show that an increased density of available L-type $\mathrm{Ca}$ channels is a concomitant of aging in hippocampal CA1 pyramidal cells (Thibault and Landfield, 1996). In addition, L-type Ca currents appear to contribute importantly to generation of the AHP and the Ca spike (Mazzanti et al., 1991b; Moyer et al., 1992; Moyer and Disterhoft, 1994), and L-channel blockers block the AHP more effectively in aged neurons (Moyer et al., 1992). Here, nimodipine also blocked more Ca current in aged neurons. Thus, an increased density of functionally available (L-type) Ca channels appears to be a strong candidate for the basis of at least some of the aging-related increase in $\mathrm{Ca}$ influx. However, it is well established that there are several functional types of high-threshold voltage-activated Ca channels (Tsien et al., 1988, 1991; Bean, 1989; Llinas et al., 1989; Miller, 1992; Catterall et al., 1993; Randall and Tsien, 1995), and multiple channel types also are present in hippocampal neurons (Fisher et al., 1990; Mogul and Fox, 1991; Regan et al., 1991; Eliot and Johnston, 1994). Therefore, it remains to be determined whether the nimodipine-sensitive current component accounts for all of the aging-related increase.

Independent of the mechanism, an increase in voltage-gated $\mathrm{Ca}$ current influx seems likely to have a wide range of functional consequences. One Ca-dependent process (the K-mediated AHP) appears to play a key role in regulating neuronal excitability (Madison and Nicoll, 1984; Storm, 1990; Lancaster and Zucker, 1994) and may modulate learning and memory processes (Disterhoft et al., 1988). Thus, an increased AHP could reduce neuronal firing rate significantly and affect cognitive functions (Moyer et al., 1992; Disterhoft et al., 1993). Consistent with this possibility is evidence that L-channel antagonists can enhance learning in aged animals (Deyo et al., 1989; Scriabine et al., 1989; McMonagleStrucko and Fanelli, 1993). Further, the increase in L-type channel density may be correlated with impaired maze performance (Thibault and Landfield, 1996).

In addition to the possible consequences of elevated $\mathrm{Ca}$ influx in the soma, it appears that synaptic function also might be affected by excess Ca influx (Landfield et al., 1986). Several functional synaptic alterations are seen during neuronal aging (Barnes and McNaughton, 1980; Smith and Rosenheimer, 1984; Bickford et al., 1986; Landfield et al., 1986; Rose et al., 1986; Bickford-Winer et al., 1988; Deupree et al., 1993) (for review, see Landfield, 1988; Barnes, 1994; Geinisman et al., 1995), and synaptic transmission of course requires $\mathrm{Ca}$ influx presynaptically and is associated with $\mathrm{Ca}$ influx postsynaptically through NMDA receptors (Mayer and Westbrook, 1987). Furthermore, recent studies have shown that synaptic input also activates voltage-gated $\mathrm{Ca}$ channels and $\mathrm{Ca}$ influx in dendrites, which, in turn, may influence conduction of EPSPs to the soma through amplification or shunting (Regehr et al., 1989; Miyakawa et al., 1992; Brown and Jaffe, 1994; Elliott et al., 1995; Magee and Johnston, 1995). Thus, altered $\mathrm{Ca}$ influx could affect a number of aspects of neuronal function in multiple compartments of the neuron.

Persistent elevation of [Ca] also can gradually induce structural degeneration or at least make neurons more vulnerable to other neurotoxic influences (Choi, 1995). Hippocampal neurons in vivo often fire $\mathrm{Na}$ action potentials in the 3-20 spikes/sec range (Barnes et al., 1983), with each spike generating $\mathrm{Ca}$ elevation of sufficient duration to sustain an AHP for 150-500 msec (Madison and Nicoll, 1984; Lancaster and Zucker, 1994). Therefore, an enhanced $\mathrm{Ca}$ influx with each action potential in aged neurons, which the present results indicate occurs, might result in an essentially continuous elevation of $[\mathrm{Ca}]$ above levels found in adult rat neurons. A persistent elevation of $\mathrm{Ca}$ influx, even of moderate proportions, could enhance the susceptibility of aging hippocampal neurons to a variety of neurotoxic and neurodegenerative processes and, in part, could account for why aging is the greatest risk factor for Alzheimer's disease (Katzman and Saitoh, 1991).

\section{REFERENCES}

Armstrong DL, Eckert R (1987) Voltage-activated calcium channels that must be phosphorylated to respond to membrane depolarization. Proc Natl Acad Sci USA 84:2518-2522.

Barnes CA (1994) Normal aging: regionally specific changes in hippocampal synaptic transmission. Trends Neurosci 17:8-13.

Barnes CA, McNaughton BL (1980) Physiological compensation for loss of afferent synapses in rat hippocampal granule cells during senescence. J Physiol (Lond) 309:473-485.

Barnes CA, McNaughton BL, O'Keffe J (1983) Loss of place specificity in hippocampal complex spike cells of senescent rat. Neurobiol Aging 4:113-119.

Bean BP (1989) Classes of calcium channels in vertebrate cells. Annu Rev Physiol 51:367-384.

Bickford PC, Hoffer BJ, Freedman R (1986) Diminished interaction of norepinephrine with climbing fiber input to cerebellar purkinje neurons in aged Fischer 344 rats. Brain Res 385:405-410. 
Bickford-Winer PC, Miller JA, Freedman R, Rose GM (1988) Agerelated reduction in responses of rat hippocampal neurons to locally applied monoamines. Neurobiol Aging 9:173-179.

Brown TH, Jaffe DB (1994) Calcium imaging in hippocampal neurons using confocal microscopy. Ann NY Acad Sci 747:313-324.

Brown TH, Fricke RA, Perkel DH (1981) Passive electrical constants in three classes of hippocampal neurons. J Neurophysiol 46:812-827.

Catterall WA, De Jongh K, Rotman E, Hell J, Westenbroek R, Dubel SJ, Snutch TP (1993) Molecular properties of calcium channels in skeletal muscle and neurons. Ann NY Acad Sci 681:342-355.

Choi DW (1995) Calcium: still center-stage in hypoxic-ischemic neuronal death. Trends Neurosci 18:58-60.

Coleman PD, Flood DG (1987) Neuron numbers and dendritic extent in normal aging and Alzheimer's disease. Neurobiol Aging 8:521-545.

Deupree DL, Bradley J, Turner DA (1993) Age-related alterations in potentiation in the CA1 region in F344 rats. Neurobiol Aging 14:249-258.

Deyo RA, Straube KT, Disterhoft JF (1989) Nimodipine facilitates associative learning in aging rabbits. Science 243:809-811.

Dingledine R (1984) Brain slices. New York: Plenum.

Disterhoft JF, Golden DT, Read HL, Coulter DA, Alkon DL (1988) AHP reductions in rabbit hippocampal neurons during conditioning correlate with acquisition of the learned response. Brain Res 462:118-125.

Disterhoft JF, Moyer JR, Thompson LT, Kowalska M (1993) Functional aspects of calcium-channel modulation. Clin Neuropharmacol 16:S12-S24.

Disterhoft JF, Gispen WH, Traber J, Khatchaturian AS (1994) Calcium hypothesis of aging and dementia. Ann NY Acad Sci 747.

Eckert R, Chad JE (1984) Inactivation of Ca channels. Prog Biophys Mol Biol 44:215-267.

Eliot LE, Johnston D (1994) Multiple components of calcium current in acutely dissociated dentate gyrus granule neurons. J Neurophysiol 27:762-777.

Elliott EM, Malouf AT, Catterall WA (1995) Role of calcium channel subtypes in calcium transients in hippocampal CA3 neurons. J Neurosci 15:6433-6444.

Fedulova SA, Kostyuk PG, Veselovsky NS (1985) Two types of calcium channels in the somatic membrane of new-born rat dorsal root ganglion neurones, J Physiol (Lond) 359:431-446.

Finkel AS, Redman SJ (1985) Optimal voltage-clamping with single microelectrodes. In: Voltage and patch clamping with microelectrodes (Smith Jr TG, Lecar H, Redman SJ, Gage PW, eds), pp 95-120. Baltimore: Williams \& Wilkins.

Fisher RE, Gray R, Johnston D (1990) Properties and distribution of single voltage-gated calcium channels in adult hippocampal neurons. J Neurophysiol 64:91-104.

Fox AP, Nowycky MC, Tsien RW (1987) Kinetics and pharmacological properties distinguishing three types of calcium currents in chick sensory neurons. J Physiol (Lond) 394:149-172.

Gähwiler BH, Brown DA (1987) Effects of dihydropyridines on calcium currents in CA3 pyramidal cells in slice cultures of rat hippocampus. Neuroscience 20:731-738.

Geinisman Y, deToledo-Morrell L, Morrell F, Heller RE (1995) Hippocampal markers of age-related memory dysfunction: behavioral, electrophysiological and morphological perspectives. Prog Neurobiol 45:223-252.

Gibson GE, Peterson C (1987) Calcium and the aging nervous system. Neurobiol Aging 8:329-343.

Hadley RW, Lederer WJ (1991) $\mathrm{Ca}^{2+}$ and voltage inactivate $\mathrm{Ca}^{2+}$ channels in guinea-pig ventricular myocytes through independent mechanisms. J Physiol (Lond) 444:257-268.

Hell JW, Westenbroek RE, Warner C, Ahlijanian MK, Prystay W, Gilbert MM, Snutch TP, Catterall WA (1993) Identification and differential subcellular localization of the neuronal Class C and Class D L-type calcium channel a1 subunits. J Cell Biol 123:949-962.

Imredy JP, Yue DT (1992) Submicroscopic $\mathrm{Ca}^{2+}$ diffusion mediates inhibitory coupling between individual $\mathrm{Ca}^{2+}$ channels. Neuron 9:197-207.

Johnston D, Hablitz JJ, Wilson WA (1980) Voltage-clamp discloses slow inward current in hippocampal burst-firing neurones. Nature 286:391-393.

Johnston D, Brown TH (1983) Interpretation of voltage-clamp measurements in hippocampal neurons. J Neurophysiol 43:409-419.
Kavalali ET, Plummer MR (1996) Multiple voltage-dependent mechanisms potentiate calcium channel activity in hippocampal neurons. J Neurosci 16:1072-1082.

Kasai H, Aosaki T (1988) Divalent cation dependent inactivation of the high-voltage-activated $\mathrm{Ca}$ channel current in chick sensory neurons. Pflügers Arch 411:695-697.

Katzman R, Saitoh T (1991) Advances in Alzheimer's disease. FASEB J 5:278-286.

Kay AR (1991) Inactivation kinetics of calcium current of acutely dissociated CA1 pyramidal cells of the mature guinea-pig hippocampus. J Physiol (Lond) 437:27-48.

Kerr DS, Campbell LW, Hao S-Y, Landfield PW (1989) Corticosteroid modulation of hippocampal potentials: increased effect with aging. Science 245:1505-1509.

Kerr DS, Campbell LW, Thibault O, Landfield PW (1992) Hippocampal glucocorticoid receptor activation enhances voltage-dependent $\mathrm{Ca}^{2+}$ conductances: relevance to brain aging. Proc Natl Acad Sci USA 89:8527-8531.

Khachaturian ZS (1984) Towards theories of brain aging. In: Handbook of studies on psychiatry and old age (Kay D, Burrows GD, eds), pp 7-30. Amsterdam: Elsevier.

Khachaturian ZS (1989) The role of calcium regulation in brain aging: reexamination of a hypothesis. Aging 1:17-34.

Kostyuk P, Pronchuk N, Savchenko A, Verkhratsky A (1993) Calcium currents in aged rat dorsal root ganglion neurones. J Physiol (Lond) 461:467-483.

Lancaster B, Zucker RS (1994) Photolytic manipulation of $\mathrm{Ca}^{2+}$ and the time course of slow, $\mathrm{Ca}^{2+}$ - activated $\mathrm{K}^{+}$current in rat hippocampal neurones. J Physiol (Lond) 475:229-239.

Landfield PW (1987) "Increased calcium current" hypothesis of brain aging. Neurobiol Aging 8:346-347.

Landfield PW (1988) Hippocampal neurobiological mechanisms of agerelated memory dysfunction. Neurobiol Aging 9:571-579.

Landfield PW (1995) Increased hippocampal $\mathrm{Ca}^{2+}$ channel activity in brain aging and dementia. Ann NY Acad Sci 747:351-364.

Landfield PW, Pitler TA (1984) Prolonged $\mathrm{Ca}^{2+}$-dependent afterhyperpolarizations in hippocampal neurons of aged rats. Science 226:1089-1092.

Landfield PW, Pitler TA, Applegate MD (1986) The effects of high $\mathrm{Mg}^{2+}$-to $\mathrm{Ca}^{2+}$ ratios on frequency potentiation in hippocampal slices of young and aged animals. J Neurophysiol 56:797-811.

Landfield PW, Thibault O, Mazzanti ML, Porter NM, Kerr DS (1992) Mechanisms of neuronal death in brain aging and Alzheimer's disease: role of endocrine-mediated calcium dyshomeostasis. J Neurobiol 23:1247-1260.

Lansman JB, Hess P, Tsien RW (1986) Blockade of current through single calcium channels by $\mathrm{Cd}^{2+}, \mathrm{Mg}^{2+}$ and $\mathrm{Ca}^{2+}$. J Gen Physiol 88:321-347.

Llinas R, Sugimori M, Lin JW, Cherskey B (1989) Blocking and isolation of a calcium channel from neurons in mammals and cephalopods utilizing a toxin fraction (FTX) from funnel-web spider poison. Proc Natl Acad Sci USA 86:1689-1693.

Madison DV, Nicoll RA (1984) Control of the repetitive discharge of rat CA1 pyramidal neurons in vitro. J Physiol (Lond) 354:319-331.

Magee JC, Johnston D (1995) Synaptic activation of voltage-gated channels in the dendrites of hippocampal pyramidal neurons. Science 268:301-304.

Martinez-Serrano A, Blanco P, Satrustegui J (1992) Calcium binding to the cytosol and calcium extrusion mechanisms in intact synaptosomes and their alterations with aging. J Biol Chem 267:4672-4679.

Mayer ML, Westbrook GL (1987) Permeation and block of N-methyl$\mathrm{D}$-aspartic acid receptor channels by divalent cations in mouse cultured central neurones. J Physiol (Lond) 394:501-527.

Mazzanti ML, DeFelice LJ, Liu Y-M (1991a) Gating of L-type $\mathrm{Ca}^{2+}$ channels in embryonic chick ventricle cells: dependence on voltage, current and channel density. J Physiol (Lond) 443:307-334.

Mazzanti ML, Thibault O, Landfield PW (1991b) Dihydropyridine modulation of normal hippocampal physiology in young and aged rats. Neurosci Res Commun 9:117-125.

McCarthy RT, TanPiengco PE (1992) Multiple types of high-threshold calcium channels in rabbit sensory neurons: high-affinity block of neuronal calcium L-type by nimodipine. J Neurosci 12:2225-2234.

McMonagle-Strucko K, Fanelli RJ (1993) Enhanced acquisition of reversal training in a spatial learning task in rats treated with chronic nimodipine. Pharmacol Biochem Behav 44:827-835. 
Michaelis ML (1994) Ion transport system and $\mathrm{Ca}^{2+}$ regulation in aging neurons. Ann NY Acad Sci 747:407-418.

Michaelis ML, Johe K, Kitos TE (1984) Age-dependent alterations in synaptic membrane systems for $\mathrm{Ca}^{2+}$ regulation. Mech Ageing Dev 25:215-225.

Michaelis ML, Foster CT, Jayawickreme C (1992) Regulation of calcium levels in brain tissue from adult and aged rats. Mech Ageing Dev 62:291-306.

Miller RJ (1992) Voltage-sensitive $\mathrm{Ca}^{2+}$ channels. J Biol Chem 267:1403-1406.

Miyakawa H, Ross WN, Jaffe D, Callaway JC, Lasser-Ross N, Lisman JE, Johnston D (1992) Synaptically activated increase in $\mathrm{Ca}^{2+}$ concentration in hippocampal CA1 pyramidal cells are primarily due to voltagegated $\mathrm{Ca}^{2+}$ channels. Neuron 9:1163-1173.

Mogul DJ, Fox AP (1991) Evidence for multiple types of $\mathrm{Ca}^{2+}$ channels in acutely isolated hippocampal CA3 neurons of the guinea-pig. J Physiol (Lond) 433:259-281.

Moyer JR, Disterhoft JF (1994) Nimodipine decreases calcium action potentials in an age- and concentration-dependent manner. Hippocampus 4:11-18.

Moyer JR, Thompson LT, Black JP, Disterhoft JF (1992) Nimodipine increases excitability of rabbit CA1 pyramidal neurons in an age- and concentration-dependent manner. J Neurophysiol 68:2100-2109.

Murchison D, Griffith WH (1995) Low-voltage activated calcium currents increase in basal forebrain neurons from aged rats. J Neurophysiol $74: 876-887$.

Nistri A, Cherubini E (1990) Inactivation of slow $\mathrm{Ca}^{2+}$ current in CA1 neurones of the adult rat hippocampal slice. Neurosci Lett 111:102-108.

Obejero-Paz CA, Jones SW, Scarpa A (1991) Calcium currents in the A7r5 smooth muscle- derived cell line. J Gen Physiol 98:1127-1140.

Peterson C, Gibson GE (1984) Aging and 3,4-diaminopyridine ameliorates deficits in calcium uptake during hypoxia. J Neurochem 42:248-252.

Pitler TA, Landfield PW (1987) Probable $\mathrm{Ca}^{2+}$-mediated inactivation of $\mathrm{Ca}^{2+}$ currents in mammalian brain neurons. Brain Res 410:147-153.

Pitler TA, Landfield PW (1990) Aging-related prolongation of calcium spike duration in rat hippocampal slice neurons. Brain Res 508:1-6.

Plummer MR, Logothetis DE, Hess P (1989) Elementary properties and pharmacological sensitivities of calcium channels in mammalian peripheral neurons. Neuron 2:1453-1463.

Potier B, Lamour Y, Dutar P (1993) Age-related alterations in the properties of hippocampal pyramidal neurons among rat strains. Neurobiol Aging 14:17-25.

Randall A, Tsien RW (1995) Pharmacological dissection of multiple types of $\mathrm{Ca}^{2+}$ channel currents in rat cerebellar granule neurons. J Neurosci 15:2995-3012.

Regan LJ, Sah DW, Bean BP (1991) $\mathrm{Ca}^{2+}$ channels in rat central and peripheral neurons: high-threshold current resistant to dihydropyridine blockers and $\omega$-conotoxin. Neuron 6:269-280.
Regehr WG, Connor JA, Tank DW (1989) Optical imaging of calcium accumulation in hippocampal pyramidal cells during synaptic activation. Nature 341:533-536.

Reynolds JN, Carlen PL (1989) Diminished calcium currents in aged hippocampal dentate gyrus granule neurones. Brain Res 479:384390.

Rose GM, Gerhardt GA, Conboy GL, Hoffer BJ (1986) Age-related alterations in monoamine release from rat striatum: an in vivo electrochemical study. Neurobiol Aging 7:77-82.

Scriabine A, Schuurman T, Traber J (1989) Pharmacological basis for the use of nimodipine in central nervous system disorders. FASEB J 3:1799-1806.

Smith DO, Rosenheimer JL (1984) Aging at the neuromuscular junction. In: Aging and cell structure (Johnson JE, ed), pp 113-139. New York: Plenum.

Spruston N, Jaffe DB, Johnston D (1994) Dendritic attenuation of synaptic potentials and currents: the role of passive membrane properties. Trends Neurosci 17:161-166.

Storm JF (1990) Potassium currents in hippocampal pyramidal cells. In: Progress in brain research (Storm-Mathisen J, Zimmer J, Ottersen OP, eds), pp 161-187. New York: Elsevier.

Swartz KJ, Bean BP (1992) Inhibition of calcium channels in rat CA3 pyramidal neurons by a metabotropic glutamate receptor. J Neurosci 12:4358-4371.

Thibault O, Landfield PW (1996) Increase in single L-type calcium channels in hippocampal neurons during aging. Science 272:10171020.

Thibault O, Porter NM, Landfield PW (1993) Low $\mathrm{Ba}^{2+}$ and $\mathrm{Ca}^{2+}$ induce a sustained high frequency of repolarization openings of L-type $\mathrm{Ca}^{2+}$ channels in hippocampal neurons: physiological implications. Proc Natl Acad Sci USA 90:11792-11796.

Thibault O, Mazzanti ML, Blalock EM, Porter NM, Landfield PW (1994) Brain neuron preparations for the study of aging changes in calcium potentials and currents. Neuroprotocols 4:177-181.

Thibault O, Porter NM, Mazzanti-Rose ML, Campbell LW, Blalock EM, Landfield PW (1995) Dual patch pipette recordings in hippocampal neurons: evidence that long $\mathrm{Ca}^{2+}$ tail currents reflect $\mathrm{Ca}^{2+}$ channel activity at resting potential. Soc Neurosci Abstr 21:1577.

Tsien RW, Lipscombe D, Madison DV, Bley KR, Fox AP (1988) Multiple types of neuronal calcium channels and their selective modulation. Trends Neurosci 11:431-437.

Tsien RW, Ellinor PT, Horne WA (1991) Molecular diversity of voltagedependent $\mathrm{Ca}^{2+}$ channels. Trends Pharmacol Sci 12:349-354.

Turner DA, Schwartzkroin PA (1984) Passive electrotonic structure and dendritic properties of hippocampal neurons. In: Brain slices (Dingledine R, ed), pp 25-50. New York: Plenum. 